\title{
Pre-release assessment of Javan Gibbon (Hylobates moloch) during acclimatization phase in Mount Malabar Protected Forest, West Java
}

\author{
Anton Ario ${ }^{1,2}$, Agus Priyono Kartono ${ }^{3}$, Lilik Budi Prasetyo ${ }^{3}$, Jatna Supriatna ${ }^{2,4}$ \\ ${ }^{1}$ Postgraduate student of Tropical Biodiversity Conservation Study Program, Bogor Agricultural \\ University, Jl. Raya Dramaga, Kampus IPB Dramaga, Bogor 16680, Indonesia, *email: \\ antonario@yahoo.com \\ ${ }^{2}$ Conservation International Indonesia, Jl. Pejaten Barat No.16A, Kemang, Jakarta 12550, Indonesia. \\ Phone/Fax. +62-21-78838626/+62-21-7806723, *email: aario@conservation.org \\ 3 Department of Forest Resource Conservation and Ecotourism, Bogor Agricultural University, Jl. Raya \\ Dramaga, Kampus IPB Dramaga, Bogor 16680, Indonesia. Phone. 0251-8628448/8622961, *email: \\ apkartono@yahoo.com; ibpras@indo.net.id \\ ${ }^{4}$ Department of Biology, University of Indonesia, Jl. Margonda Raya, Depok 16424, West Java, Indonesia. \\ Phone/Fax. +62-21-7270163/+62-21-78849010, *email: jatna.supriatna@gmail.com
}

\begin{abstract}
The treatment processes before Javan gibbons (Hylobates moloch) release include rehabilitation, translocation, and acclimatization. Preparation for gibbons before being released into their habitat is crucial. Thus, there is a need for readiness assessment of Javan gibbon with several criteria derived from other species of gibbons to determine individual readiness. Pre-release assessment research during acclimatization phase for Javan gibbon had been conducted in February-March 2014, February-March 2015, March-April 2015, and July-August 2016. The objective of this research was to assess the readiness of Javan gibbon behavior prior to release in acclimatization phase. Data collection was conducted by focal animal sampling method with 5-minute interval recording time and ad libitum method. The average time allocation of Javan gibbon activities during acclimatization phase were the following:

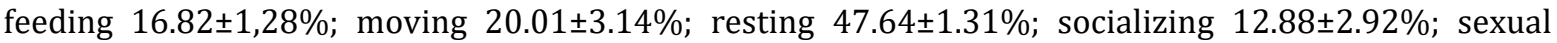
$0.69 \pm 0.54 \%$; and vocalizing $1.96 \pm 0.59 \%$. We compared activity allocation data from this study and those from wild Javan gibbons and found similarities as follows: $55.30 \%$ at a family of Jowo-Bombom-yaniYudi, $51.42 \%$ at a pair of Moly-Nancy, $44.57 \%$ at a pair of Robin-Moni and $62.19 \%$ at a family of MelPooh-Asri. Based on readiness assessment of 11 Javan gibbons, 3 were considered almost ready for release, while 8 individuals were considered ready. The assessment of behaviors criteria for the readiness of Javan gibbons before release in acclimatization phase has not existed before. The results of this research are important as a recommendation for the management of wildlife rehabilitation and as a guideline in implementing the rehabilitation and reintroduction program of Javan gibbons.
\end{abstract}

Keywords: assessment, acclimatization, behavior, Javan gibbon, pre-release

Citation: Ario, A., Kartono, A. P., Prasetyo, L. B., dan Supriatna, J. (2019). Pre-release assessment of Javan Gibbon (Hylobates moloch) during acclimatization phase in Mount Malabar Protected Forest, West Java. Jurnal Ilmu Lingkungan, 17(2), 189-196, doi:10.14710/jil.17.2.189-196

\section{Introduction}

The rehabilitation program of Javan gibbon (Hylobates moloch) established since 2003 at the Javan Gibbon Centre (JGC), located inside of the Mount Gede Pangrango National Park. The aim of the centre is to rehabilitate ex-captive Javan gibbons, returning them to full physical, psychological health, behaviour, with a view to releasing suitable pairs and family groups into suitable protected habitat. Reintroduction program of Javan gibbon begin since 2009, then established since 2013 in Mount Malabar Protected Forest. After transferred to release site, the Javan gibbons required acclimatization phase.

All pre-release gibbons should ideally spend some time acclimatizing to a semi-natural environment (or half-way house). Gibbons should never be released immediately after transport to 
the release area: time is required to recover from the stress of the trip and for acclimatization. Ideally, gibbons should be released into an enclosed environment, where they cannot migrate and where observers can easily monitor the gibbons (Strum \& Southwick 1986).

Soft release, in the case of gibbon translocation, is defined in terms of provision of an acclimatization enclosure within the release site. A minimum period of three weeks should allow some level of adaptation to the new environment and assessment of likely interference from other gibbons in the area. Additional time would be required should gibbons fail to demonstrate key essential survival behaviours (Cheyne et al. 2008). It is not recommended for immediate removal at reintroduction sites as it takes time to relieve the stress experienced during displacement. In addition, acclimatization cages can help animals to adapt first to a new environment (Cheyne 2012).

Depending on the size of the enclosure, care should be taken to avoid an overly extended period that may result in the deterioration of positive behaviours. A soft release would ensure the demonstration of appropriate behaviours and calling as triggers prior to release from a soft release cage (Campbell et al.,2015).

Acclimatization cages serve the purpose of allowing sensory adaptation to the new environment, as well as assessment of potential interference from other gibbons or species. They should be large enough to allow for normal behaviours and preferably be larger than the gibbons' previous enclosure, though this is not always possible due to terrain at release sites. It is also important to consider that the size is sufficient should there be unforeseen delays in the release (Campbell et al.,2015).

Transfer to the new environment may well result in the reoccurrence of previously displayed negative behaviours, such as moving to the ground, cessation of calling and stereotypic behaviors (Ario, pers. comm. 2013). These behaviours may be due to stress of the new surroundings, but may also be an indicator of difficulty in adapting to new surroundings and careful assessment should be made prior to release. Gibbons should not be spending any time on the ground of the enclosure, as this is likely to increase risk of predation after release (Campbell et al.,2015).

Close observation of gibbons whilst housed in the acclimatization enclosure is important to ensure there is no injury or onset of medical or behavioural abnormalities. Ideally, the gibbon will not be handled during the acclimatization phase (Campbell et al.,2015). Therefore, to ensure that individual Javan gibbons that will be released do not decrease the quality of health and behavior, it is necessary to assess individuals of Javan gibbon during acclimatization phase before it is released.

\section{Materials and Methods \\ Time and Location of Study}

The research was conducted in gradually during acclimatization phase in February-March 2014, February-March 2015, March-April 2015, and JulyAugust 2016 in Mount Malabar Protected Forest (MMPF). It has an area of about 8.894,47 hectares located in Bandung Regency, West Java. The research site was located at $07^{\circ} 07^{\prime} 20.52^{\prime \prime} \mathrm{S}$ and $107^{\circ} 36^{\prime} 28.48^{\prime \prime}$ $\mathrm{E}$, at altitudes of 1,000 to $2,300 \mathrm{~m}$ asl (Fig 1). The average temperature was $18-23{ }^{\circ} \mathrm{C}$ with annual rainfall between 2,000 and $2,500 \mathrm{~mm}$.

\section{Research Subjects}

The subjects of this research are 11 Javan gibbons scheduled for release. The gibbons are the family of Jowo-Bombom-Yani-Yudi, pair of Robin-Moni, pair of Moli-Nancy, and family of Mel-Pooh-Asri (Table 1 ). The age level of observed gibbons consisted of 8 adults: Jowo, Bombom, Nancy, Moli, Moni, Robin, Mel, and Pooh with average age $\pm 11-19$ years; one adolescent: Yani aged \pm 4 years, and 2 infants: Yudi aged \pm 1 year and Asri aged \pm 6 months (Table 1 ). Age category for Javan gibbon is divided into adult for > 6 years old, adolescent at 4-6 years old, juvenile at 2-4 years old, and infant at 0-2 years old (Kappeler 1981 and Leighton 1986).

\section{Data Collection and Analyses}

Behaviors observed in this research consist of feeding, moving, resting, socializing, sexual, and vocalization. Behavior data sampling utilized focalanimal sampling method, with 5 minute intervals between observations (Altmann 1974), during gibbon active period from waking up in the morning until they sleep in the late afternoon (Cocks 2000). Data sampling is also combined with ad libitum method, by taking notes on important happenings outside the observation period (Martin \& Bateson 2007).

In this research, the sampling duration for each group were 30 days. During February-March 2014, we observerb family of Jowo-Bombom-Yani-Yudi, February-March 2015 for pair of Moli-Nancy, March-April 2015 for pair of Robin-Moni, then JulyAugust 2016 for family of Mel-Pooh-Asri.

To determine Javan gibbon pair bond, observation on proximity and distance between individuals within a group is decided as: (1) less than $1 \mathrm{~m}$ with contact, (2) less than $1 \mathrm{~m}$ without contact, (3) 1-5 m, and (4) more than $5 \mathrm{~m}$. Cage strata usage pattern is also observed, separated into 4 regions: cage ground or terrestrial $(0-2 \mathrm{~m})$, strata 1 which is the lower part of the cage $(2-4 \mathrm{~m})$, strata 2 which is the middle part of the cage (4-6m), and strata 3 which is the upper part of the cage $(>6 \mathrm{~m})$.

There are 9 parameters in Javan gibbon behavioral readiness, which are the proportion of feeding, moving, resting, sexual, grooming, 
agonistic, solo female call (morning call), stereotypic, and human directed behavior. Javan gibbon behavioral readiness parameter is a modification from behavioral readiness parameter proposed by Cheyne et al. (2012) for Hylobates agilis. Every parameter is assumed to have different importance in supporting survival in the wild. Thus, in determining criteria and parameter value, behavior data from wild Javan gibbon is used based on literature study.

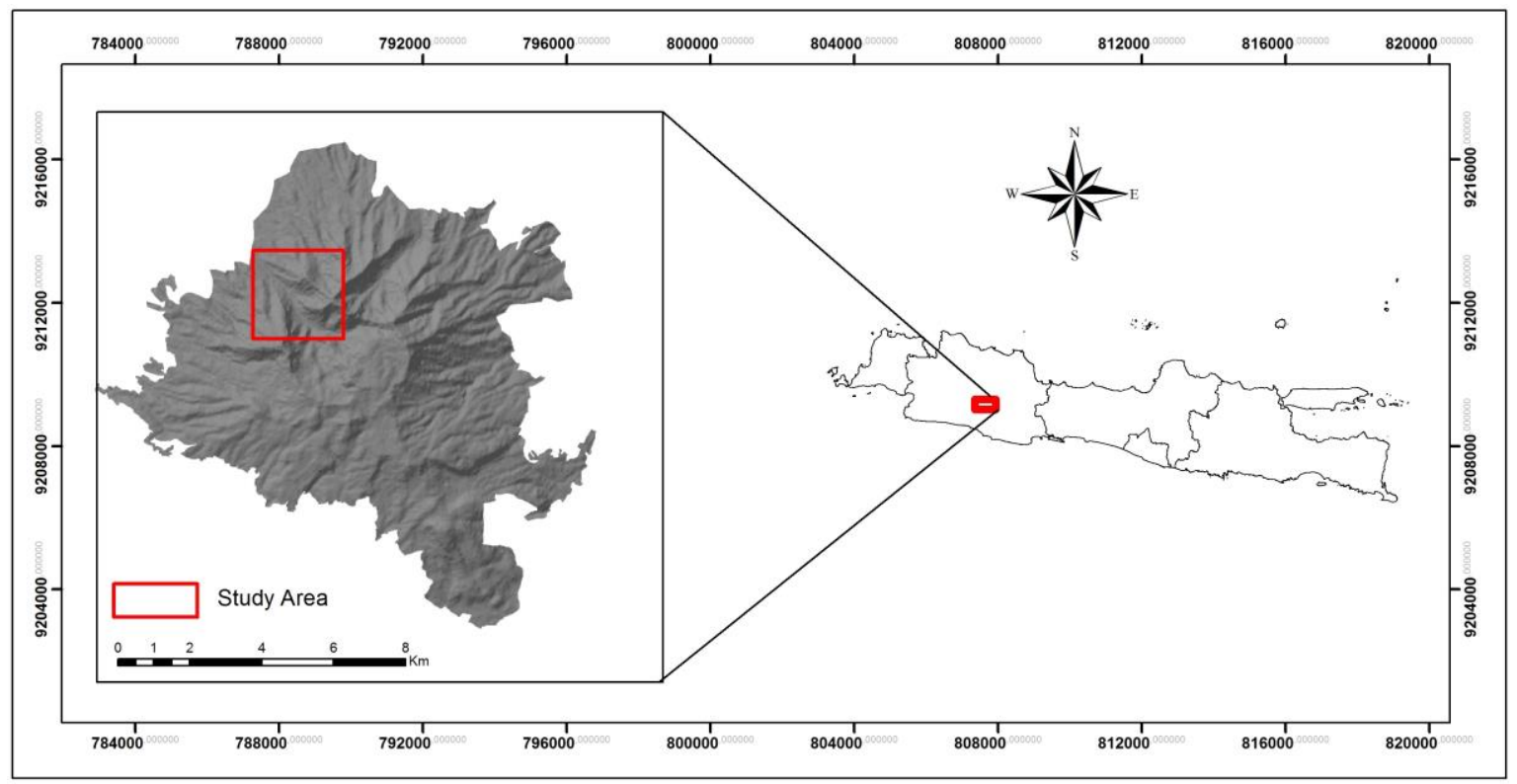

Figure 1. The map of study area in MMPF

Table 1. The age level of observed javan gibbons

\begin{tabular}{|c|c|c|c|c|c|}
\hline Nick Name & Sex & Estimated Birth & $\begin{array}{c}\text { Rehabilitation } \\
\text { Phase }\end{array}$ & $\begin{array}{c}\text { Acclimatization } \\
\text { Phase }\end{array}$ & $\begin{array}{l}\text { Group } \\
\text { Status }\end{array}$ \\
\hline Jowo & $\mathrm{M}$ & 1999 & $2008-2014$ ( \pm 6 years $)$ & 26 February-26 March 2014 & \\
\hline Bombom & $\mathrm{F}$ & 1999 & $2008-2014$ ( \pm 6 years $)$ & & Family \\
\hline Yani & $\mathrm{F}$ & 21 July 2010 & $2010-2014( \pm 4$ years $)$ & & \\
\hline Yudi & $\mathrm{M}$ & 7 July 2013 & $2014( \pm 1$ year $)$ & & \\
\hline Nancy & $\mathrm{F}$ & 1998 & 2004-2015 ( \pm 11 years $)$ & 1 January-23 April 2015 & Pair \\
\hline Moli & $\mathrm{M}$ & 2002 & 2004-2015 ( \pm 11 years $)$ & & \\
\hline Moni & $\mathrm{F}$ & 2004 & $2005-2015$ ( \pm 10 years $)$ & 1 January-23 April 2015 & Pair \\
\hline Robin & $\mathrm{M}$ & 2002 & $2008-2015( \pm 7$ years $)$ & & \\
\hline Mel & M & 1997 & $2008-2016( \pm 8$ years $)$ & 18 April-9 August 2016 & \\
\hline Pooh & $\mathrm{F}$ & 2000 & $2008-2016$ ( \pm 8 years $)$ & & Family \\
\hline Asri & $\mathrm{F}$ & 9 Feb 2015 & $2015-2016( \pm 1$ year $)$ & & \\
\hline
\end{tabular}

Obtained Javan gibbon behavioral data are analyzed by qualitative approach. Examination results are given score between 1,3 , and 5 and valued based on similarity between rehabilitated with wild Javan gibbon. Score analysis and value weighting are utilizing Likert scale. The use of every unit from every point was valid, for every option was an indicator of its represented variable (Budiaji 2013). Javan gibbon readiness for release is divided into 3 categories, not ready with the total value of 100-233, almost ready with 234-366, and ready 367-500.

The results of individual preparedness category of Javan gibbon during acclimatization phase are used in determining three subsequent decision criteria's i.e. not to proceed to release, proceed to release but extending for acclimatization time, and proceed to release (Table 2).

Table 2. Decision criteria's in acclimatization phase (Modified from Campbell et al.,2015)

\begin{tabular}{lll}
\hline Category & Decision & Criteria's \\
\hline Not ready & Not to proceed to release & $\begin{array}{l}\text { If the gibbons show drastic decline in behavior and health. This is indicated by } \\
\text { the inability of individual Javan gibbon to restore physical condition and health } \\
\text { after three weeks of acclimatization. The decision taken is to return the Javan } \\
\text { gibbon to the rehabilitation center }\end{array}$ \\
\hline Almost ready & $\begin{array}{l}\text { Proceed to release but extending } \\
\text { for acclimatization time }\end{array}$ & $\begin{array}{l}\text { If the gibbons show behavioral and health instability after three weeks of } \\
\text { acclimatization. }\end{array}$ \\
\hline Ready & Proceed to release & $\begin{array}{l}\text { If the gibbons show behavior and stable health even tend to show improvement } \\
\text { of positive behavior among individuals }\end{array}$ \\
\hline
\end{tabular}




\section{Results and Discussion \\ Activity budget of Javan gibbon}

Javan gibbon daily activity in acclimatization phase was recorded to begin in the morning at 6:00 a.m. and ended at 16:00 p.m.. Total research observation hours were 285 hours for each observed Javan gibbon. The average daily activity was recorded to be 9 to 10 hours per day for each animal. This period is still within Hylobatidae active hours stated by Leighton (1986), which is 8 to 10 hours per day.
We analyzed the behavioral data and found that the eleven released Javan gibbons allocated their time as on table 3. Several studies on wild Javan gibbon behavior in Mount Gede-Pangrango National Park (MGPNP), Mount Halimun National Park (MHNP), and Leuweung Sancang Nature Reserve (LSNR) found that the average time (\%) allocation was: feeding $39.20 \pm 6.84 \%$, moving $24.56 \pm 11.29 \%$, resting $28.30 \pm 9.61 \%$, socializing $3.46 \pm 1.91 \%$, vocalizing $3.17 \pm 2.80 \%$ and sexual $1.30 \pm 0.24$ (Landjar 1996; Fithriyani 2007; Iskandar 2007; Arifin 2007; Malone 2007; and Ario 2011).

Table 3. Behavioral time allocation for each group of pre-release Javan gibbons (\%)

\begin{tabular}{lllll}
\hline Behaviors & $\begin{array}{l}\text { The family of Jowo- } \\
\text { Bombom-Yani-Yudi }\end{array}$ & $\begin{array}{l}\text { The pair of } \\
\text { Moli-Nancy }\end{array}$ & $\begin{array}{l}\text { The pair of } \\
\text { Robin-Moni }\end{array}$ & $\begin{array}{l}\text { The family of } \\
\text { Mel-Pooh-Asri }\end{array}$ \\
\hline Feeding & $16.77 \pm 2.28$ & $18.58 \pm 2.02$ & $16.36 \pm 3.09$ & $15.56 \pm 3.69$ \\
Moving & $21.34 \pm 2.22$ & $22.76 \pm 4.33$ & $15.54 \pm 2.46$ & $20.41 \pm 3.78$ \\
Resting & $46.77 \pm 4.88$ & $46.39 \pm 2.15$ & $49.23 \pm 6.25$ & $48.17 \pm 6.20$ \\
Socializing & $12.18 \pm 6.36$ & $10.24 \pm 0.02$ & $17.06 \pm 0.48$ & $12.03 \pm 8.96$ \\
Vocalizing & $2.47 \pm 1.42$ & $1.80 \pm 0.18$ & $1.19 \pm 0.19$ & $2.36 \pm 1.73$ \\
Sexual & $5.53 \pm 9.84$ & $0.22 \pm 0.00$ & $0.60 \pm 0.02$ & $1.47 \pm 1.31$ \\
\hline
\end{tabular}

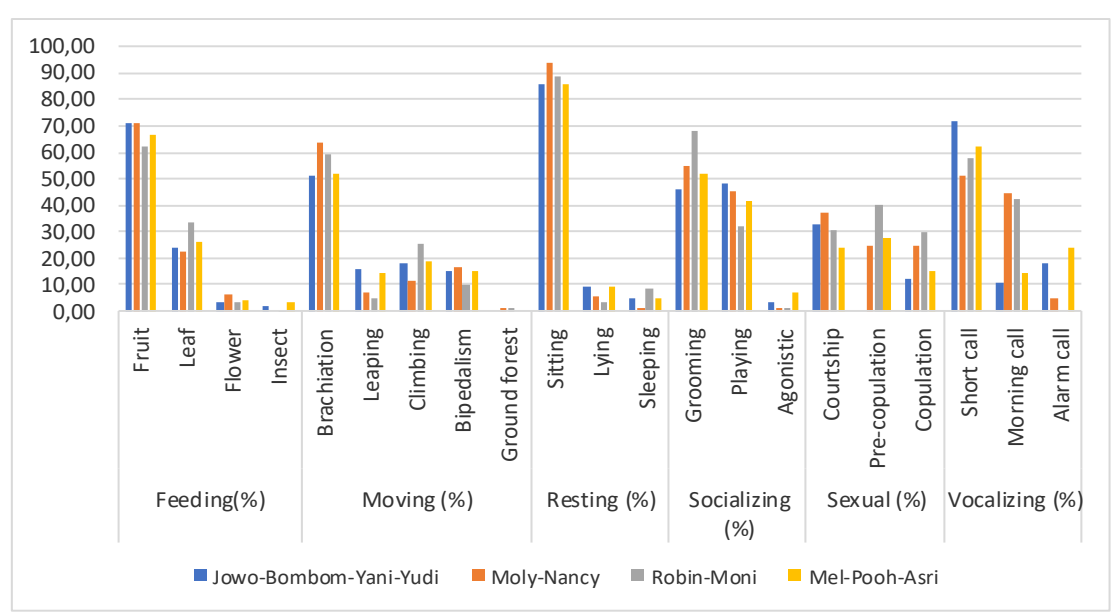

Figure 2. Average percentage for each gibbons group behavi

The gibbons mostly ate fruits $67.74 \pm 4.21$, followed by leaves $26.49 \pm 5.09$, flowers $4.34 \pm 1.52$ and insects $1.43 \pm 1.51$. Brachiation $56.50 \pm 6.18$ was the primary locomotion, followed by climbing 18.30 \pm 5.76 , bipedalism 14.22 \pm 3.02 , and leaping 10.53 \pm 5.53 . They rested by sitting $88.44 \pm 3.65$, lying $6.76 \pm 2.98$, and sleeping $4.79 \pm 2.96$. Social interaction among individuals was grooming 55.23 \pm 9.37 , playing $41.64 \pm 7.22$, and agonistic behavior 3.12 \pm 2.60 . Sexual behavior between adults was as follow: courtship 31.15 \pm 5.67 , pre-copulation $30.87 \pm 8.21$, and copulation behavior $20.61 \pm 8.32$. The gibbons mostly vocalized by doing short call 60.58 \pm 8.58 , followed by morning call $27.91 \pm 17.84$, and alarm call 15.35 \pm 9.74 . Grooming, playing, and sexual are included in affiliative interaction among Javan gibbon. Average percentage behaviors for each gibbons group found as figure 2 .

We proved this from the average proximity among individuals in each group as follow: $46,13 \%$ for $<1 \mathrm{~m}$ with direct contact, $27,42 \%<1 \mathrm{~m}$ without contact, $24,65 \% 1-5 \mathrm{~m}$, and 1,80\%. $>5 \mathrm{~m}$. The average of cages strata used in each group as follow: 4,19\% terrestrial part of the cage (0-2m), $31.18 \%$ lower strata $(2-4 \mathrm{~m}), 57,78 \%$ middle strata (4-6m) dan 6,85\% upper strata $(>6 \mathrm{~m})$.

\section{Behaviour Similarity Level}

We compared behavior allocation data from this study and data from wild Javan gibbon and found as on table 4.

Javan gibbons start to increase their activity during feeding time. Feeding activity of Javan gibbons at the acclimatization cages happened during feeding time, which was 7:00 a.m., 10:00 a.m., 12:00 a.m., and 2:00 p.m.. These showed that the binodal pattern that was stated by Ravasi (2004) did not occur in the daily activity of Javan gibbons living at the cages. 
Other than consuming market fruits (non-forest fruit), Javan gibbons have been introduced to forest fruit since entering acclimatization phase. Because since in rehabilitation phase, the strategy of introducing forest fruits occurred since beginning, to the gibbons eventually grew accustomed to forest fruit feed.

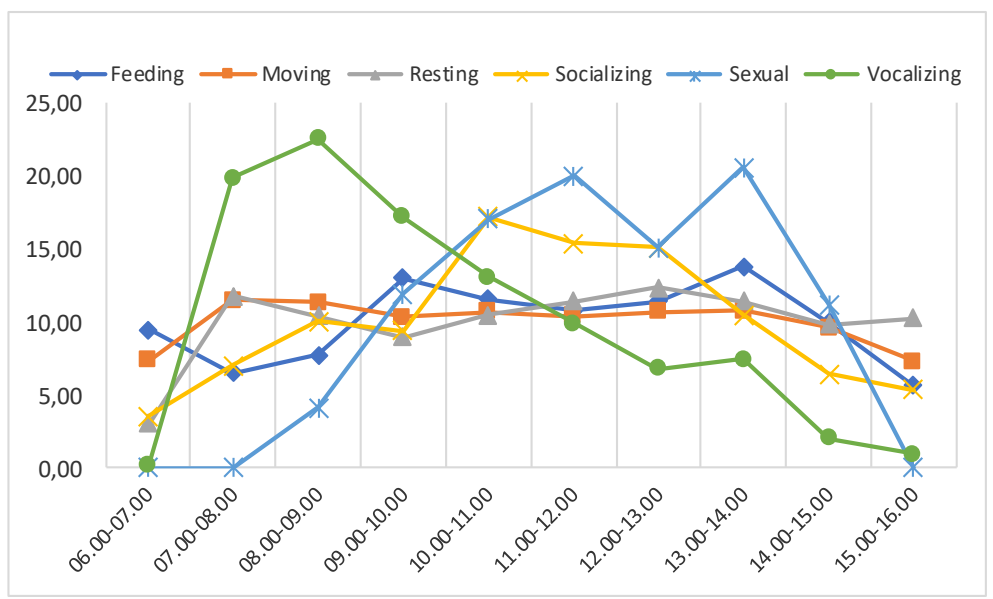

Figure 3. Daily activity patterns of the Javan gibbons in acclimatization phase

Table 4. Similarity level data on pre-release and wild Javan gibbons

\begin{tabular}{ccccccc}
\hline & & \multicolumn{5}{c}{ Similarity level (\%) } \\
\cline { 3 - 7 } Behavior & $\begin{array}{c}\text { 'ild Javan Gibbons } \\
( \pm \text { SD })\end{array}$ & $\begin{array}{c}\text { The family of Jowo- } \\
\text { mbom-Yani-Yudi }\end{array}$ & $\begin{array}{c}\text { The pair of } \\
\text { Moli-Nancy }\end{array}$ & $\begin{array}{c}\text { The pair of } \\
\text { Robin-Moni }\end{array}$ & $\begin{array}{c}\text { 2 family of Mel-Pooh- } \\
\text { Asri }\end{array}$ & Average \\
\hline Feeding & $39.20 \pm 6.84$ & 42.79 & 47.40 & 41.75 & 39.70 & 42.91 \\
Moving & $24.56 \pm 11.29$ & 86.90 & 92.69 & 63.27 & 83.09 & 81.49 \\
Resting & $28.30 \pm 9.61$ & 60.51 & 61.00 & 57.49 & 58.75 & 59.44 \\
Socializing & $3.46 \pm 1.91$ & 28.38 & 33.79 & 20.28 & 28.76 & 27.80 \\
Vocalizing & $3.17 \pm 2.80$ & 77.84 & 56.72 & 37.70 & 74.37 & 61.66 \\
Sexual & $1.30 \pm 0.24$ & 35.38 & 16.92 & 46.92 & 88.44 & 49.62 \\
\hline
\end{tabular}

There are 10 types of forest fruits that have been consumed by Javan gibbons at the acclimatization cages, which consist of: beunying (Ficus pistulosa), darangdang (Ficus sinuate), hampelas (Ficus hampelas), kondang (Ficus variegate), harendong (Melastoma affine), pisitan monyet (Dysoxylum aliaceum), hamirung (Vernonea arborea), walen (Ficus ribes), rasamala (Altingia excelsa), and nangsi (Villebrunea rubescens).

The average percentage of fruit eaten was more than $50 \%$ and the rest of their intake consisted of leaves, flowers, and insects, showing that Javan gibbons during their acclimatization process are already used to eating fruits. Javan gibbon's ability to find and consume forest fruit is important for their survival post-release.

As a frugivore, Javan gibbon consumed more fruits (61\%), compared to bud and young leaves (38\%), and flowers (1\%), coming from 125 types of plants in total. Javan gibbons also consumed several types of insects, such as termites (Kappeler 1981; Supriatna \& Wahyono 2000).

The differences average similarity of behavioral allocation of Javan gibbon in acclimatization phase compared to wild Javan gibbon. These were caused by research of Javan gibbon being limited in cages, which caused their activities also be limited. A difference in daily behavior time allocation were caused by different habitat condition (Kakati et al. 2009).

Highest similarity percentage was found in moving behavior, since every Javan gibbon has been placed in acclimatization cage which has more room for moving space, with combined width of all sides being around $60-80 \mathrm{~m}^{2}$ and height $7-10 \mathrm{~m}$. The gibbons can brachiate, leap, climb, and walk bipedally by using the movement tools such as ropes and bamboos. Brachiation movement has the highest percentage compared to leaping, climbing, and bipedalsm movement. Matsumoto-Oda \& Oda (1998) stated that gibbon's main movement is brachiation, which is moving horizontally by using two arms to support body weight and swing from tree branches to another. The other types of movement are climbing, leaping, and bipedalsm movement.

The high percentage of middle strata space usage in Javan gibbon behavior is because the moving tools such as the ropes and bamboos are mostly placed in the strata. Placement of moving 
space in the middle strata can avoid usage of lower stratra or the cage floor space. Allowing Javan gibbon to use the lower strata is very risky as this behaviour would result in greater chance of predation after release. The acclimated Javan gibbons were still seen using the cage ground to move, although the average percentage is relatively low on $0.45 \%$. The allocation of behavior by the lower strata of the cage may not exceed $5 \%$, as it will increase the risk of predation (Cheyne 2004).

The lowest similarity percentage was found in social activity. In the cages, social interaction between gibbons to happen often. The high interaction was also caused by the presence of infant and juvenile in Jowo-Bombom-Yani-Yudi family and Mel-Pooh-Asri family, which increased grooming behavior from mother to infant and juvenile and also playing between infant and juvenile. Based on the proximity between animal data, it showed that the bond of Javan gibbons are relatively strong. A strong bond between pairs is crucial before release. The pairs which would be released must be able to copulate (Ravasi 2004 and Cheyne 2004).

\section{Javan Gibbon Individual Readiness}

In 9 behavioral parameters used to assess Javan gibbon behavioral ability it was shown that feeding, moving, resting, grooming, and agnostic activity can be conducted by the 11 Javan gibbons with different allocation for each animal. Morning call activity is only done by adult female in every group, and stereotypic and human directed behavior is not shown by every individual (Table 5 ).

Table 5. The average percentage of every behavioral readiness parameter of Javan gibbon

\begin{tabular}{|c|c|c|c|c|c|c|c|c|c|}
\hline \multirow[t]{2}{*}{ Individual } & \multicolumn{8}{|c|}{ Behaviour Parameter (\%) } & \multirow[b]{2}{*}{ Hbd } \\
\hline & $\mathbf{F}$ & $\mathbf{M}$ & $\mathbf{R}$ & $\mathbf{S}$ & G & $\mathbf{A}$ & Mc & St & \\
\hline Jowo & 19.70 & 18.68 & 51.74 & 0.92 & 5.86 & 0.41 & 0.00 & 0.00 & 0.00 \\
\hline Bombom & 17,02 & 20.34 & 50.08 & 0.92 & 6.24 & 0.41 & 1.75 & 0.00 & 0.00 \\
\hline Yani & 16.16 & 23.18 & 43.58 & 0.00 & 6.31 & 0.16 & 0.00 & 0.00 & 0.00 \\
\hline Yudi & 14.22 & 23.18 & 41.70 & 0.00 & 6.31 & 0.16 & 0.00 & 0.00 & 0.00 \\
\hline Moli & 17.15 & 25.82 & 44.87 & 0.22 & 5.53 & 4.72 & 0.00 & 0.00 & 0.00 \\
\hline Nancy & 20.01 & 19.70 & 47.92 & 0.22 & 5.50 & 4.72 & 1.71 & 0.00 & 0.00 \\
\hline Robin & 14.18 & 13.80 & 53.65 & 0.59 & 6.14 & 0.00 & 0.00 & 0.00 & 0.00 \\
\hline Moni & 18.55 & 17.28 & 44.82 & 0.62 & 6.53 & 0.03 & 1.12 & 0.00 & 0.00 \\
\hline Mel & 17.70 & 19.20 & 52.45 & 1.92 & 5.88 & 0.32 & 0.00 & 0.00 & 0.00 \\
\hline Pooh & 17.70 & 17.38 & 51.01 & 2.50 & 5.88 & 1.12 & 0.76 & 0.00 & 0.00 \\
\hline Asri & 11.30 & 24.64 & 41.06 & 0.00 & 6.33 & 0.09 & 0.00 & 0.00 & 0.00 \\
\hline
\end{tabular}

Remarks: F=feeding, $M=-$ moving, $R=$ resting, $S=$ sexual, $G=$ grooming, $A=$ Agonistic, $M c=$ Morning call,

St=Stereotypic, Hdb=Human directed behavior

Based on 11 Javan gibbon behavioral readiness, 8 adults were within ready, 1 adolescent, 1 juveniles and 1 infant were almost ready for release (Table 6) The highest parameter value in readiness was scored by adult females in the following order: Nancy, Moni, Bombom and Pooh. This is because of morning call behavior existing only in adult female. The average morning call percentage done by adult female of overall vocalization behavior. Morning call behavior prompted mutual reply from every cage during acclimatization phase. The vocalization occured by Javan gibbon sence since they were in rehabilitation phase.
Morning calls by adult females are a territorial marking that shows that even if caged, the territorial system is very strong in every Javan gibbon group. A morning call vocalization by an adult female is a way to communicate with other groups and to show the range for her territory (Kappeler 1981). This was in line with what was stated by Geissmann et al. (2005), that vocalization behavior in Javan gibbon exhibit unique characteristic compared to other Hylobatidae, for the female has a larger role in protecting territory

Table 6. Individual result of Javan gibbon pre-release behavioral readiness

\begin{tabular}{lcl}
\hline Individual & Total value & Categories \\
\hline Jowo & 380 & Ready (interval 367-500) \\
Bombom & 410 & Ready (interval 367-500) \\
Yani & 338 & Almost ready (interval 234-366) \\
Yudi & 334 & Almost ready (interval 234-366) \\
Moli & 398 & Ready (interval 367-500) \\
Nancy & 406 & Ready (interval 367-500) \\
Robin & 380 & Ready (interval 367-500) \\
Moni & 430 & Ready (interval 367-500) \\
Mel & 414 & Ready (interval 367-500) \\
Pooh & 438 & Ready (interval 367-500) \\
Asri & 332 & Almost ready (interval 234-366) \\
\hline
\end{tabular}


Other than the morning call, another important vocalization displayed by Javan gibbon is an alarm call by both male and female adults, which at times is followed by their offspring. Alarm calls were made whenever a potentially dangerous object or threat was observed by the group, such as wild boar, snake, or javan leopard. Early warning is very important so that Javan gibbon can detect the possibility of threat such as leopard (Supriatna \& Wahyono 2000). It would be a very beneficial skill upon release to the wild. Awareness is one of the purposes of living in group, for each member of the family has the role of detecting trouble/foreign objects in their surrounding environments. The functional role of every member of the family is to detect danger in their environment, allowing them to detect predators earlier (Napier \& Napier 1985 and Schaik 1985 in Tobing 2002).

The average affiliative percentage value is higher compared to agonistic value. This showed that positive bonding has been formed between the members of Javan gibbon groups. Affiliative form observed are grooming, playing, and courtship. Sussman et al. (2004) in Asteria (2008) stated that interaction within groups consist of affiliative and agonistic interaction. Affiliative interactions are interactions that strengthen bond and improve relationship between members. Affiliative behavior in primates has the function of preserving pairbonds and influencing other animal (Koontz \& Roush 1996, Fuentes 2002), including courtship (Estep \& Desbury 1996).

The lowest final value in individual readiness is found in young gibbons, in the order: Yani, Asri, and Yudi. This was caused by the age level which means there was still behavioral limitation and they were still undergoing the learning process from their parents. Moreover, infants are still carried by the parent, although occasionally separated from the mother for self-learning.

Although the young gibbons have lower readiness value, the presence of strong bonds will allow them to be released along with the parents. Along with age growth, they will improve their natural behavior. Gibbons are not released individually, but rather as pairs or family units. Generally, in infant and juvenile, they tend to display playing behavior, as seen in family Jowo-Bombom-Yani-Yudi and family MelPooh-Asri. Playing is one form of social pair-bond (Thompson 1996). Another social pair-bond behavior is autogrooming (Esteps \& Desbury 1996). Current recommendations are for the release of gibbons compatible pairs or family groups, reducing theinitial energy investment in searching for a mate (Campbell et al.,2015).

The 11 Javan gibbon observed did not exhibit stereotypic behavior. Stereotypic behaviors are behaviors with a repetitive fixed movement pattern. This behavior often serves no definite function or clear purpose. Stereotypic behaviors are one of the indicators that an animal has been subjected to an unsuitable environment for a long period of time in captivity. Animals in captivity are prone to exhibit such behavior for the limited space for movement in the cages (Caristead 1996). Stereotypic behavior not more than $3 \%$ can be eliminated by doing daily activities in nature (Cheyne 2004).

Human directed behavior, showing interest or desire to get close, was not shown by the 11 soon to be released Javan gibbon. This is because during in acclimatization process, interaction with human only occured with keepers during feeding times. Limiting direct interaction with humans is an effective method in eliminating un natural behaviors. After release, cages should be left open at the release site, so that the gibbons can use them as sleeping sites and to provide a familiar object in a strange place. Food (ideally natural foods found within the release site) can also be provisioned near the cage immediately after release, but should be gradually reduced to encourage foraging and reduce dependence (Campbell et al.,2015).

\section{Conclusions}

Acclimatization is an important process that must be done for the Javan gibbons that will be released. Pre-release Javan gibbon needs to be assessed for behavioral readiness especially for feeding, moving, resting, sexual, grooming, agonistic, morning call, stereotypic behaviour, and human directed behavior. Almost ready to ready categoring in observed Javan gibbon showed that acclimatization effort is beneficial for the 11 Javan gibbon that are scheduled for release. It's should ideally be a well-bonded pair or family unit be a strong candidates for released.

\section{Acknowledgements}

We thank Conservation International Indonesia, Javan Gibbon Foundation, Mount Gede Pangrango National Park, Forestry State Enterprise of Regional Division of West Java-Banten, and the Agency for Conservation of Natural Resources of West Java. We would like to also thank Clare Campbell and Holly Thompson from Wildlife Asia and Silvery Gibbon Project, Arcus Foundation, Full Circle Foundation and PT. Pertamina EP Asset 3 Subang Field, who have supported the Javan gibbon rehabilitation and reintroduction program. We thank the Javan gibbon monitoring team in Gunung Puntang: Mulya Hermansyah, Eryan Hidayat, Uwas, Yanto, Asep Sunarya, Agus Setiawan, Jenal, Nandang, and Ade Candra.

\section{References}

Altmann, J. 1974. Observational study of behavior: Sampling methods. Behaviour 49 (3):227-267.

Arifin, S. 2007. Pola aktivitas harian owa jawa (Hylobates moloch Audebert, 1978) di hutan Rasamala Resot Bodogol Taman Nasional Gunung Gede Pangrango. [Skripsi]. Bogor (ID): Universitas Ibnu Khaldun.

(C) 2019, Program Studi Ilmu Lingkungan Sekolah Pascasarjana UNDIP 
Ario, A. 2011. Aktivitas harian owa jawa (Hylobates moloch Audebert 1798) rehabilitan di blok hutan patiwel, Taman Nasional Gunung Gede Pangrango. Dalam: Kumpulan Hasil-hasil Penelitian Owa jawa di Bodogol Taman Nasional Gunung Gede Pangrango Periode 2000-2010. Ario A, Supriatna J, Andayani N (ed).13-29. Jakarta (ID): Conservation International Indonesia.

Asteria, 2008. Interaksi sosial dalam kelompok Gorila (Gorilla gorilla, Savage \& Wyman 1847) di Pusat Primata Schmutzer, Taman Margasatwa Ragunan. [Skripsi]. Jakarta (ID): Universitas Indonesia.

Budiaji, W. 2013. Skala pengukuran dan jumlah respon skala Likert. Jurnal Ilmu Pertanian dan Perikanan Desember 2013 Vol. 2 No. 2:125-131

Caristead, K. 1996. Effect of captivity on the behavior of wild mammals. In: Kleiman, DG., Allen, M., Thompson, KV., Lumpkin, S. 1996. Wild mammals in captivity: Principles and techniques. London (GB). University of Chicago Press: 317-333.

Campbell, CO., Cheyne, SM., Rawson, BM. 2015. Best Practice Guidelines for the Rehabilitation and Translocation of Gibbons. Gland, Switzerland: IUCN SSC Primate Specialist Group.

Cheyne, SM. 2004. Assessing rehabilitation and reintroduction of captive-raised gibbons in Indonesia. PhD Thesis. University of Cambridge, Cambridge (UK): xviii +231

Cheyne SM, Chivers DJ, Sugardjito J. 2008. Biology and behavior of reintroduced gibbons. Biodiversity Conservation 17:1741-1751.

Cheyne, SM., Campbell, C., Payne KL. 2012. Proposed guidelines for in situ gibbon rescue, rehabilitation and reintroduction. International Zoo Yearbook 46:1-17.

Cocks, LR. 2000. International Studbook for Silvery Gibbon (Hylobates moloch). Western Australia (AU). Perth Zoo:28.

Estep, DQ., Dewsbury, DA. 1996. Mammalian reproductive behavior. In: Kleiman, DG., Allen, M., Thompson, KV., Lumpkin, S. 1996. Wild mammals in captivity: Principles and techniques. London (GB). University of Chicago Press: 379-389.

Fithriyani, U. 2007. Variasi pola pakan antar kelompok owa jawa (Hylobates moloch Audebert 1798) di Bodogol, Taman Nasional Gunung Gede Pangrango, Jawa Barat. [Skripsi]. Jakarta (ID): Universitas Negeri Jakarta.

Fuentes, A. 2002. Patterns and trends in primate pair bonds. International Journal of Primatology 23(5): 953-978.

Geissmann, T., Bohlen, ES., Heuck, A. 2005. The male song of the Javan silvery gibbon (Hylobates moloch). Contribution to Zoology 74(1/2):1-25.
Iskandar, S. 2007. Perilaku dan penggunaan habitat kelompok owa Jawa di hutan Rasamala Taman Nasional Gunung Gede-Pangrango. [Tesis]. Jakarta (ID): Universitas Indonesia.

Kakati, KR., Raghavan, R., Chellam, QQ., Chivers, DJ. 2009. Status of western hoolock gibbon (Hoolock hoolock) populations in fragmented forest of Eastern Assam. Primate Conservation 24:1-11.

Kappeler, M. 1981. The Javan silvery gibbon (Hylobates lar moloch). Ph.D. [Thesis]. Universität Basel.1-40.

Koontz, FW., Roush, RS. 1996. Communication and social behavior. In: Kleiman, DG., Allen, M., Thompson, KV., Lumpkin, S. 1996. Wild mammals in captivity: Principles and techniques. London (GB). University of Chicago Press: 334-343.

Ladjar, LN. 1996. Aktivitas harian dan penggunaan habitat pada keluarga owa jawa (Hylobates moloch AUDEBERT, 1798) liar di Cikaniki, Taman Nasional Gunung Halimun, Jawa Barat. [Skripsi]. Jakarta (ID): Universitas Nasional.

Leighton, DN. 1986. Gibbons: territoriality and monogamy. In: Smuts, BB., Cheyne, DL., Seyfarth, RM., Wranghamj, RW., Struhsaker, TT (eds.). Primate societies. Chicago (US). University of Chicago: 135-145

Malone, NM. 2007. The socioecology of the critically endangered Javan gibbon (Hylobates moloch); Assessing the impact of anthropogenic disturbance on primate social systems. (Doctoral Dissertation). Portland (US): University of Oregon.

Martin, P., Bateson, P. 2007. Measuring behavior: An introductory guide. $3^{\text {rd }}$ ed. Cambridge (GB): Cambridge University Press: 176.

Matsumoto-Oda, A., Oda, R. 1998. Changes in activity budget of cycling female Chimapanzes. American Journal of Primatology 46: 157-166.

Ravasi, D. 2004. Phuket's forest sings again. The Gibbon Rehabilitation Project, Phuket. Thailand.

Rinaldi D. 2003. The study of javan gibbon (Hylobates moloch Audebert) in Gunung Halimun National Park (Distribution, population and behavior). Research and conservation of biodiversity in Indonesia 9:30-47.

Strum SC, Southwick CH. 1986. Translocation of Primates. In: Benirschke K (ed). Primates: The Road to Selfsustaining Populations. New York (US): Springer Verlag. 949-957.

Supriatna, J., Wahyono, EH. 2000. Panduan Lapangan Primata Indonesia. Jakarta (ID): Yayasan Obor Indonesia.

Tobing, ISL. 2002. Respon primata terhadap kehadiran manusia di kawasan Cikaniki, Taman Nasional Gunung Halimun. Berita Biologi. 6. 